\title{
Effect of diet composition and ration size on key enzyme activities of glycolysis-gluconeogenesis, the pentose phosphate pathway and amino acid metabolism in liver of gilthead sea bream (Sparus aurata)
}

\author{
I. Metón ${ }^{1}$, D. Mediavilla ${ }^{1}$, A. Caseras ${ }^{1}$, E. Cantó ${ }^{1 *}$, F. Fernández ${ }^{2}$ and I. V. Baanante ${ }^{1} \dagger$ \\ ${ }^{1}$ Departament de Bioquímica i Biologia Molecular, Facultat de Farmàcia, Universitat de Barcelona, Barcelona, Spain \\ ${ }^{2}$ Departament d'Ecologia, Facultat de Biologia, Universitat de Barcelona, Barcelona, Spain
}

(Received 4 December 1998 - Revised 29 March 1999 - Accepted 20 May 1999)

\begin{abstract}
The effects of diet composition and ration size on the activities of key enzymes involved in intermediary metabolism were studied in the liver of gilthead sea bream (Sparus aurata). Highcarbohydrate, low-protein diets stimulated 6-phosphofructo 1-kinase (EC 2.7.1.11), pyruvate kinase (EC 2.7.1.40), glucose-6-phosphate dehydrogenase (EC 1.1.1.49) and 6-phosphogluconate dehydrogenase ( $E C$ 1.1.1.44) enzyme activities, while they decreased alanine aminotransferase (EC 2.6.1.2) activity. A high degree of correlation was found between food ration size and the activity of the enzymes 6-phosphofructo 1-kinase, pyruvate kinase, glucose-6-phosphate dehydrogenase (positive correlations) and fructose-1,6-bisphosphatase (EC 3.1.3.11) (negative correlation). These correlations matched well with the high correlation also found between ration size and growth rate in starved fish refed for $22 \mathrm{~d}$. Limited feeding ( $5 \mathrm{~g} / \mathrm{kg}$ body weight) for $22 \mathrm{~d}$ decreased the activities of the key enzymes for glycolysis and lipogenesis, and alanine aminotransferase activity. The findings presented here indicate a high level of metabolic adaptation to both diet type and ration size. In particular, adaptation of enzyme activities to the consumption of a diet with a high carbohydrate level suggests that a carnivorous fish like Sparus aurata can tolerate partial replacement of protein by carbohydrate in the commercial diets supplied in culture. The relationship between enzyme activities, ration size and fish growth indicates that the enzymes quickly respond to dietary manipulations of cultured fish.
\end{abstract}

Sparus aurata: Glycolysis: Gluconeogenesis: Amino acids

The use of nutrients by carnivorous fish differs from that of the rat and other carnivorous mammals. Glycaemia is less well regulated than in mammals, and the capacity to metabolize glucose is diminished (Cowey \& Walton, 1989; Steffens, 1989). Most key enzymes for carbohydrate metabolic pathways are apparently found in fish, and the basis for the low ability of carnivorous fish to utilize carbohydrates remains unclear (Wilson, 1994). Omnivorous fish such as carp (Cyprinus carpio) (Furuichi \& Yone, 1981) have a higher capacity to metabolize glucose than carnivorous fish, although this is lower than in mammals.

We have previously shown that starvation-refeeding and differences in diet composition promote changes in the levels of enzyme activities involved in intermediary metabolism in the liver of gilthead sea bream (Sparus aurata) (Baanante et al. 1991). Nowadays Sparus aurata is one of the most extensively cultured marine fish in the
Mediterranean countries. The cost of the diets supplied to gilthead sea bream in culture is high because of the high protein content required, usually provided by fish meal.

Somatic factors, such as body and liver weight, and metabolic factors, such as metabolite and enzyme activity determinations, are currently used to determine the capacity for metabolic adaptation to dietary supply in fish. In this regard, the liver-somatic index (LSI), hepatic glycogen content and key liver enzyme activities of intermediary metabolism have been shown to match well with the nutritional status and the growth rate in fish (Bonamusa et al. 1989, 1992; Bastrop et al. 1992; Brauge et al. 1994; Pelletier et al. 1994). Important in this respect are 6-phosphofructo 1-kinase (PFK-1; EC 2.7.1.11) and pyruvate kinase (PK; EC 2.7.1.40), key enzymes for glycolysis; fructose-1,6-bisphosphatase (FBPase-1; EC 3.1.3.11), in relation to gluconeogenesis; glucose-6-phosphate dehydrogenase (G6P-DH;

\footnotetext{
Abbreviations: ALT, alanine aminotransferase; AST, aspartate aminotransferase; BW, body weight; FBPase-1, fructose-1,6-bisphosphatase; G6P-DH, glucose-6-phosphate dehydrogenase; LSI, liver-somatic index; PFK-1, 6-phosphofructo 1-kinase; 6PG-DH, 6-phosphogluconate dehydrogenase; PK, pyruvate kinase.

* Present address: Departament d'Immunologia, Hospital de la Santa Creu i Sant Pau, 08025 Barcelona, Spain.

$\dagger$ Corresponding author: Dr Isabel V. Baanante, fax +34 3402 1896, email baanante@farmacia.far.ub.es
} 
EC 1.1.1.49) and 6-phosphogluconate dehydrogenase activity (6PG-DH; EC 1.1.1.43), involved in the pentose phosphate pathway; alanine aminotransferase (ALT; EC 2.6.1.2) and aspartate aminotransferase (AST; EC 2.6.1.1), related to amino acid metabolism.

The aim of the present study was to evaluate in detail the changes promoted in intermediary metabolism in the liver of Sparus aurata following feeding or refeeding after starvation with diets containing different levels of protein, carbohydrate and lipids, or with different amounts of a given diet. In addition, as growth was determined at different daily ration sizes, the present work may also contribute to establishing a relationship between biochemical variables and growth rates.

\section{Materials and methods}

Gilthead sea bream fish were obtained from Aquadelt S.A. (Deltebre, Tarragona, Spain), and were maintained in 250litre aquaria supplied with running sea-water at $20^{\circ}$ in a closed system with active pump filter and u.v. lamps. Photoperiod was regulated as a dark-light cycle of $12 \mathrm{~h}$.

The effect of diet composition supplied to Sparus aurata was studied using the diets shown in Table 1. To study the effects of diet composition on key enzymes involved in glycolysis-gluconeogenesis, the pentose phosphate pathway and amino acid metabolism in the liver, five different diets were supplied to the fish. Proportions of ingredients in the diets were selected to cover a wide range above and below the levels in diets available commercially. Analyses of the diets were performed following standard procedures (Windham, 1997). Three levels of protein were selected $(380,480$ and $580 \mathrm{~g} / \mathrm{kg}$ ) and the proportions of gelatinized starch and fish-liver oil were adjusted to achieve two energy levels (about 19 and $20 \mathrm{~kJ} / \mathrm{g}$ ) for each level of protein, except for the $580 \mathrm{~g}$ protein $/ \mathrm{kg}$ level, for which only one level of energy $(19 \mathrm{~kJ} / \mathrm{g})$ was designed. The diets are ordered by carbohydrate content in all tables. The fish were fed on the different diets at $20 \mathrm{~g} / \mathrm{kg}$ body weight (BW) for $18 \mathrm{~d}$ (fed fish), then starved for $19 \mathrm{~d}$ and finally refed for $8 \mathrm{~d}$ with the corresponding diet at $20 \mathrm{~g} / \mathrm{kg} \mathrm{BW}$. Two aquaria were used for each diet treatment, each stocked with twenty-five fish with an average weight of 25 (SD 3.6) g.

In order to study the nutritional regulation due to the quantity of diet supplied to animals, fish were starved for $8 \mathrm{~d}$ and then refed for $22 \mathrm{~d}$. Refed fish were divided into four groups, receiving diet 3 (Table 1) once daily at 5, 10, 20 or $35 \mathrm{~g} / \mathrm{kg} \mathrm{BW}$ respectively. Two aquaria were used for each treatment, with thirty-six to thirty-eight fish per aquarium with an average weight of 9.4 (SD 1.6) g.

All fish in each aquarium were weighed at the start and end of a given feeding regimen. They were also weighed at intervals of $7-8 \mathrm{~d}$, to readjust ration size, when the total feeding period was longer than $8 \mathrm{~d}$.

To obtain tissue samples, fish were anaesthetized with 3aminobenzoic acid ethyl ester $(1: 12500)$ and were then killed by cervical section. The liver was dissected out, immediately frozen in liquid $\mathrm{N}_{2}$ and kept at $-80^{\circ}$ until use. Six to twelve fish were killed per treatment and sampling period.

The LSI was calculated as liver weight/BW $\times 100$, where $\mathrm{BW}$ represents fresh $\mathrm{BW}$ of fish.

Liver glycogen was determined spectrophotometrically at $620 \mathrm{~nm}$ using the anthrone reaction method according to García de Frutos et al. (1990). The glycogen content is expressed in $\mathrm{mg}$ glucose equivalent per $100 \mathrm{mg}$ fresh liver tissue.

Crude extracts for assaying enzyme activities were

Table 1. Composition ( $\mathrm{g} / \mathrm{kg}$ diet) of the different types of diet provided to Sparus aurata*

\begin{tabular}{|c|c|c|c|c|c|}
\hline & Diet 1 & Diet 2 & Diet 3 & Diet 4 & Diet 5 \\
\hline \multicolumn{6}{|l|}{ Formulation } \\
\hline Brown fish meal† & 91.40 & $81 \cdot 74$ & $81 \cdot 74$ & 64.35 & 64.35 \\
\hline Fish oilł & 2.50 & 6.58 & $2 \cdot 33$ & 9.06 & 4.82 \\
\hline Starch§ & 3.60 & $9 \cdot 18$ & $13 \cdot 43$ & 24.09 & 28.33 \\
\hline Vitamin mixture $\|$ & 0.47 & 0.47 & 0.47 & 0.47 & 0.47 \\
\hline Carrageenan & $2 \cdot 00$ & $2 \cdot 00$ & $2 \cdot 00$ & $2 \cdot 00$ & $2 \cdot 00$ \\
\hline $\mathrm{BHT}$ & 0.03 & 0.03 & 0.03 & 0.03 & 0.03 \\
\hline \multicolumn{6}{|l|}{ Chemical analysis } \\
\hline Moisture & $2 \cdot 6$ & 3.0 & $2 \cdot 8$ & $3 \cdot 1$ & 3.4 \\
\hline Protein & 58.5 & $47 \cdot 7$ & $47 \cdot 6$ & 37.9 & 37.4 \\
\hline Fat & $8 \cdot 7$ & $16 \cdot 2$ & $12 \cdot 5$ & $16 \cdot 9$ & 11.6 \\
\hline Carbohydrate & 9.9 & $13 \cdot 1$ & $17 \cdot 1$ & $26 \cdot 0$ & $31 \cdot 6$ \\
\hline Ash & $20 \cdot 3$ & $20 \cdot 0$ & $20 \cdot 0$ & $16 \cdot 1$ & $16 \cdot 0$ \\
\hline Gross energy $(\mathrm{kJ} / \mathrm{g})^{\star *}$ & $19 \cdot 1$ & $20 \cdot 0$ & $19 \cdot 2$ & $20 \cdot 1$ & 18.9 \\
\hline
\end{tabular}

BHT, butylated hydroxytoluene.

* Diets used in this study were designed by us and manufactured by Dalgety España S.A. (Castellbisbal, Barcelona, Spain).

† Whole fish and trash fish meal from Induxtra (Banyoles, Girona, Spain).

†Fish oil with added all-trans retinol $(300 \mu \mathrm{g} / \mathrm{g})$ and cholecalciferol $(2.5 \mu \mathrm{g} / \mathrm{g})$ from Bonafont Química (Barcelona, Spain).

$\S$ Gelatinized maize starch from Campo Ebro (Zaragoza, Spain).

$\|$ Vitamin mixture provided (/kg diet): all-trans retinol $11.28 \mathrm{mg}$, cholecalciferol $117.5 \mu \mathrm{g}$, choline chloride $1.88 \mathrm{~g}$, ascorbic acid $1.18 \mathrm{~g}$, nicotinic acid $160 \mathrm{mg}$, all-rac-tocopherol acetate $118 \mathrm{mg}$, thiamin- $\mathrm{HCl} 118 \mathrm{mg}$, calcium pantothenate $94 \mathrm{mg}$, riboflavin $71 \mathrm{mg}$, pyridoxine- $\mathrm{HCl} 24 \mathrm{mg}$, menadione- $\mathrm{HNaSO}_{3} 19 \mathrm{mg}$, pteroylmonoglutamic acid $14 \mathrm{mg}$, cyanocobalamin $0.37 \mathrm{mg}$.

I Analysis of the diets followed standard procedures (Windham, 1997); carbohydrate was calculated by difference.

${ }^{* *}$ Calculated from gross composition (protein $24 \mathrm{~kJ} / \mathrm{g}$, lipid $39 \mathrm{~kJ} / \mathrm{g}$, carbohydrate $17 \mathrm{~kJ} / \mathrm{g}$ ). 
obtained by homogenization of the powdered frozen liver $(1: 5, \mathrm{w} / \mathrm{v})$ in $50 \mathrm{mM}$-Tris-HCl $\mathrm{pH} 7 \cdot 5,4 \mathrm{mM}$-EDTA, $50 \mathrm{mM}-\mathrm{NaF}, 0.5 \mathrm{mM}$-phenylmethylsulfonyl fluoride, $1 \mathrm{mM}-$ 1,4-dithiothreitol and $250 \mathrm{mM}$-sucrose using a PTA-7 Polytron (Kinematica GmbH, Littau-Luzern, Switzerland) (position 3, 30 s), and centrifugation at $20000 \mathrm{~g}$ for $30 \mathrm{~min}$ at $4^{\circ}$.

Assays for PFK-1, PK, FBPase-1, G6P-DH and 6PG-DH activities and total protein were adapted for automated measurement using a Cobas Mira S spectrophotometric analyser (Hoffman-La Roche, Basel, Switzerland), based on previously described methods (Bonamusa et al. 1992). ALT and AST were assayed with kits from Roche for routine determinations in Cobas Mira S. All enzyme assays were carried out at $30^{\circ}$ and followed at $340 \mathrm{~nm}$.

PFK-1 activity was assayed in a final volume of $200 \mu \mathrm{l}$ containing: $100 \mathrm{mM}-$ Tris- $\mathrm{HCl}$ pH $8.25, \quad 5 \mathrm{mM}-\mathrm{MgCl}_{2}$, $50 \mathrm{~mm}-\mathrm{KCl}, \quad 0 \cdot 15 \mathrm{mM}-\mathrm{NADH}, 4 \mathrm{mM}$-ammonium sulfate, $12 \mathrm{~mm}$-2-mercaptoethanol, $10 \mathrm{~mm}$-fructose 6-phosphate, $30 \mathrm{mM}$-glucose 6 -phosphate, $0.675 \mathrm{U} / \mathrm{ml}$ fructose bisphosphate aldolase (EC 4.1.2.13), $5 \mathrm{U} / \mathrm{ml}$ triose-phosphate isomerase $(E C$ 5.3.1.1), $2 \mathrm{U} / \mathrm{ml}$ glycerol-3-phosphate dehydrogenase (EC 1.1.99.5) and $4 \mu \mathrm{l}$ crude extract. The PFK-1 reaction was measured after addition of $1 \mathrm{mM}$-ATP.

The specific assay conditions for PK activity were: $250 \mu \mathrm{l}$

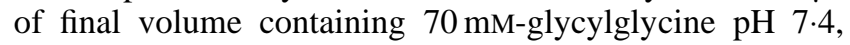
$10 \mathrm{mM}-\mathrm{MgCl}_{2}, \quad 100 \mathrm{mM}-\mathrm{KCl}, \quad 0.15 \mathrm{mM}-\mathrm{NADH}, \quad 2.8 \mathrm{mM}-$ phosphoenolpyruvate, $21 \mathrm{U} / \mathrm{ml}$ lactate dehydrogenase $(E C$ 1.1.1.27) and $2.5 \mu \mathrm{l}$ sample. ADP (2.5 mmol/l) was added to monitor the PK reaction.

FBPase-1 activity was assessed in a final volume of $200 \mu \mathrm{l}$ with $85 \mathrm{mM}$-imidazole- $\mathrm{HCl} \mathrm{pH} 7.7,5 \mathrm{mM}-\mathrm{MgCl}_{2}$, 0.5 mM-NADP, 12 mM-2-mercaptoethanol, 0.05 mM-fructose1,6-bisphosphate, $2.5 \mathrm{U} / \mathrm{ml}$ phosphate-glucose isomerase (EC 5.3.1.9), $0.48 \mathrm{U} / \mathrm{ml} \mathrm{G6P-DH}$ and $4 \mu \mathrm{l}$ crude extract.

G6P-DH activity was measured using $4 \mu \mathrm{l}$ sample in a final volume of $200 \mu \mathrm{l}$ containing $78 \mathrm{mM}$-imidazole- $\mathrm{HCl}$ $\mathrm{pH} 7 \cdot 7,5 \mathrm{mM}-\mathrm{MgCl}_{2}, 1 \mathrm{mM}-\mathrm{NADP}$ and $1 \mathrm{mM}$-glucose 6phosphate.

The assay conditions for 6PG-DH activity were: $83 \mathrm{mM}-$ imidazole-HCl pH 7.7, 3 mM- $\mathrm{MgCl}_{2}, 0.5 \mathrm{mM}-\mathrm{NADP}, 2 \mathrm{mM}-$ 6-phosphogluconate and $4 \mu \mathrm{l}$ crude extract in a final volume of $200 \mu$.

The total protein content was determined in Cobas Mira $\mathrm{S}$ at $600 \mathrm{~nm}$ by the Bradford (1976) method at $30^{\circ}$ in liver crude extracts using bovine serum albumin as a standard.

Specific growth rates (SGR) were calculated for each aquarium (fish were not marked individually, to avoid possible stress and/or infections), according to the expression: SGR $(\% / d)=(\operatorname{lnBWf}-\operatorname{lnBWi}) \times 100 /$ number of days, where $\mathrm{BWi}$ and BWf were the mean initial and final fresh weight of fish.

Data were analysed by one-factor ANOVA using a computer program (SuperANOVA, Abacus Concepts, Inc., Berkeley, CA, USA). Differences were determined according to Duncan's multiple range test, with significance levels at $P<0.05$ and $P<0.01$. Figures and correlations were constructed with the help of the KaleidaGraph program (KaleidaGraph, Synergy Software, PCS Inc., Reading, PA, USA).

\section{Results \\ Effect of diet composition}

The LSI was dependent on the type of diet supplied (Fig. 1(a)). After the initial $18 \mathrm{~d}$ feeding period, fish fed on diet 1 , which had the highest protein content and the lowest carbohydrate level, showed the lowest LSI values, whereas fish fed on diets 3 and 5, with the same energy content as diet 1 but with a higher carbohydrate: protein ratio showed the highest LSI values. Diets 2 and 4 with higher energy (and lipid) contents than the other diets, presented intermediate values, even though diet 4 contained more carbohydrate than diet 3 . Comparison of the groups fed on diets with similar protein levels but different energy contents indicated that higher LSI values were observed in fish fed on the lower energy diet (with high carbohydrate: lipid ratio). On the other hand, a $19 \mathrm{~d}$ period of starvation resulted in a decrease in the LSI in all groups of fish studied. In starved fish, the higher decrease appeared in fish previously fed on diets containing the highest carbohydrate : lipid ratio at a similar protein level (diets 3 and 5 compared with diets 2 and 4 respectively). After $8 \mathrm{~d}$ refeeding, higher LSI values were found again in the groups of fish refed on diets 3 and 5, although complete recovery or even higher values than those observed in fed fish were achieved only by the fish fed on diets 1 and 4 (Fig. 1(a)).

Fed fish showed a dependence of the hepatic glycogen levels on the type of diet supplied (Table 2). Carbohydrate content of the diets seemed to be the main conditioning factor. Those animals fed on high-carbohydrate, low-protein diets (diets 4 and 5) showed the highest levels of glycogen, whereas diets 1 and 2, with the lowest carbohydrate: protein ratios, led to the lowest glycogen levels. Moreover, fish fed on diet $2(130 \mathrm{~g}$ carbohydrates $/ \mathrm{kg})$, showed a lower level of hepatic glycogen than diet 3 even though energy (or lipid) content of diet 2 was higher than diet 3 and both contained the same amount of protein. In all groups of fish studied, starvation for $19 \mathrm{~d}$ was also accompanied by a highly significant decrease in liver glycogen. Refeeding restored the values to those observed in fed fish (control), however the time-course of recovery depended on the composition of the diet. One day of refeeding was sufficient for fish to recover the levels of glycogen when refed on low-carbohydrate diets (diets 1 and 2). Those refed on high-carbohydrate, low-protein diets (diets 4 and 5) did not reach control values until day 3 (Table 2).

The liver PFK-1, PK, G6P-DH and 6PG-DH activities showed a dependence on the levels of carbohydrate and protein in the diets. In the liver of fish fed on diet 5 (316g carbohydrate and $374 \mathrm{~g}$ protein $/ \mathrm{kg}$ ) all values were between 1.6- and 2-fold higher than those observed in fish fed on diet 1 (115 g carbohydrate and $583 \mathrm{~g}$ protein/ $\mathrm{kg}$ ) (Table 3).

After $19 \mathrm{~d}$ starvation, glycolytic (PFK-1, PK) and pentose phosphate pathway (G6P-DH, 6PG-DH) enzyme activities had decreased significantly. PFK-1 enzyme activity showed an almost full recovery after $1 \mathrm{~d}$ of refeeding. However, only a slight recovery was observed in PK activity values.

G6P-DH and 6PG-DH activities decreased in fish starved for $19 \mathrm{~d}$ and, after $8 \mathrm{~d}$ of refeeding, higher activities were found in fish fed on high-carbohydrate, low-lipid diets (diets 3 and 5) than in those fed on diets of high lipid content (diets 2 and 4). 
(a)

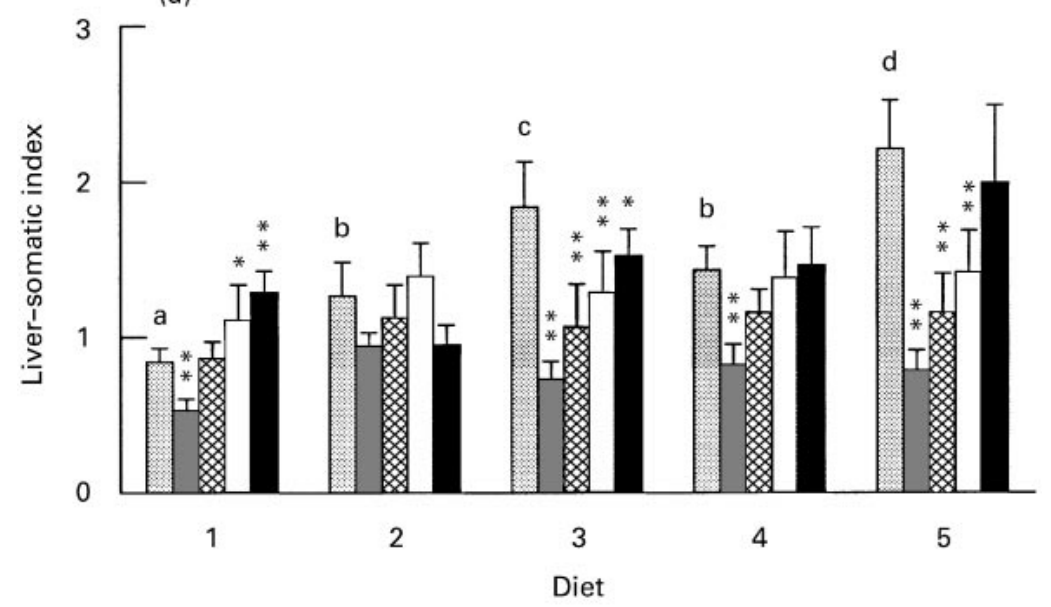

(b)

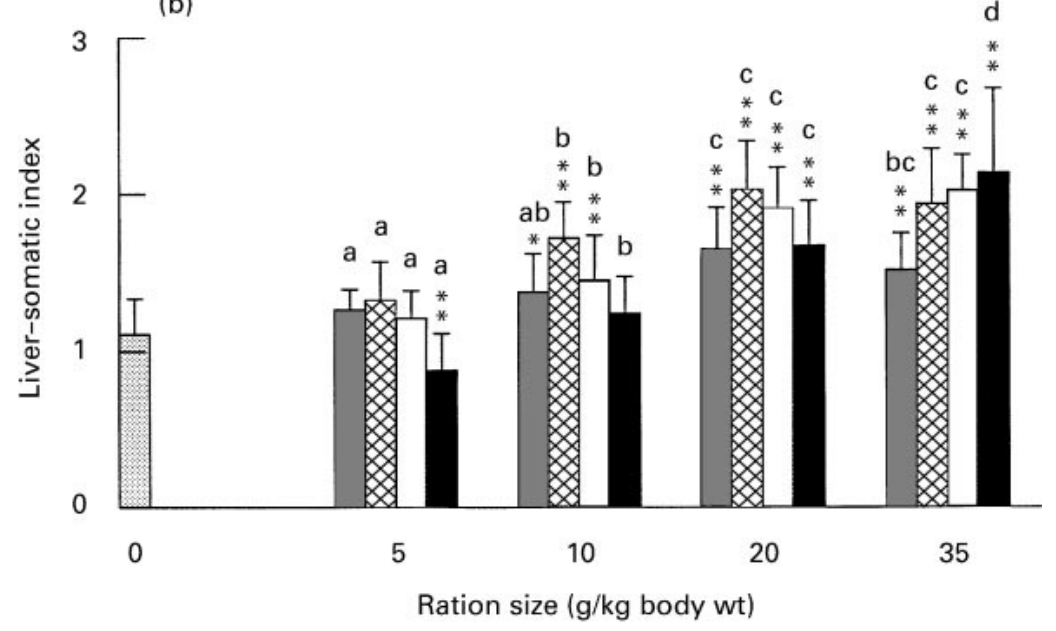

Fig. 1. (a) Liver-somatic index values (liver weight/body weight $\times 100$ ) in gilthead sea bream fed, starved and subsequently refed on diets of different composition (diets 1-5,

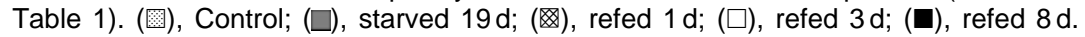
Values are means for at least four fish, with their standard errors indicated by vertical bars. Statistical significance was determined by Duncan's multiple range test. ${ }^{a, b, c, d}$ Mean values for control groups with unlike letters were significantly different, $P<0.05$. Mean values were significantly different from those for the corresponding control: ${ }^{*} P<0.05,{ }^{* *} P$ $<0.01$. (b) Liver-somatic index values in gilthead sea bream refed on diet 3 (Table 1 ) at $5,10,20$ or $35 \mathrm{~g} / \mathrm{kg}$ body weight after an $8 \mathrm{~d}$ period of starvation. (畨), Starved $8 \mathrm{~d} ;(\square)$, refed $1 \mathrm{~d}$; (网), refed $3 \mathrm{~d} ;(\square)$, refed $8 \mathrm{~d}$; $(\square)$, refed $22 \mathrm{~d}$. Values are means for at least four fish, with their standard errors indicated by vertical bars. ${ }^{a, b, c, d}$ Mean values not sharing a common letter were significantly different, $P<0.05$ (Duncan's multiple range test). Mean values were signifcantly different from those for starved fish: ${ }^{\star} P<0.05,{ }^{\star \star} P<0.01$.

Table 2. Liver glycogen levels ( $\mathrm{mg} / \mathrm{g}$ fresh liver) in gilthead sea bream fed, starved and subsequently refed on diets of different composition† (Mean values and standard deviations for three fish)

\begin{tabular}{|c|c|c|c|c|c|c|c|c|c|c|}
\hline & \multicolumn{2}{|c|}{ Fed } & \multicolumn{2}{|c|}{ Starved $19 \mathrm{~d}$} & \multicolumn{2}{|c|}{ Refed $1 \mathrm{~d}$} & \multicolumn{2}{|c|}{ Refed 3d } & \multicolumn{2}{|c|}{ Refed $8 d$} \\
\hline Diet 1 & $62 \cdot 6^{\mathrm{ab}}$ & 13 & $2 \cdot 7^{b * *}$ & 1.0 & $74 \cdot 4^{b}$ & $28(n 5)$ & $103 \cdot 2^{b *}$ & $20(n 4)$ & $102 \cdot 1^{b}$ & 3 \\
\hline Diet 3 & $84 \cdot 3^{b c}$ & 7 & $0.7^{a \star *}$ & 0.2 & $38 \cdot 3^{a \star \star}$ & 2 & $96 \cdot 9^{b}$ & 14 & $138 \cdot 2^{\mathrm{c} * *}$ & 4 \\
\hline Diet 4 & $140 \cdot 2^{d}$ & 36 & $1 \cdot 1^{a * *}$ & 0.2 & $20 \cdot 9^{a * *}$ & $\overline{6}$ & $126 \cdot 0^{\mathrm{b}}$ & 19 & $180 \cdot 3^{d *}$ & 9 \\
\hline Diet 5 & $117 \cdot 2^{\text {cd }}$ & 21 & $1 \cdot 0^{a * *}$ & 0.1 & $35 \cdot 7^{a * *}$ & 23 & $109.0^{\mathrm{b}}$ & 24 & $146 \cdot 6^{c}$ & 11 \\
\hline
\end{tabular}

a,b,c,d Mean values within a column not sharing a common superscript letter were significantly different, $P<0.05$.

Mean values were significantly different from those for the corresponding fed fish: ${ }^{\star} P<0.05,{ }^{\star \star} P<0.01$.

†For details of diets and procedures, see Table 1 and pp. 224-225. 
Table 3. Activities ( $\mathrm{mU} / \mathrm{mg}$ protein) of 6-phosphofructo 1-kinase (PFK-1), pyruvate kinase (PK), fructose-1,6-bisphosphatase (FBPase-1), glucose-6-phosphate dehydrogenase (G6P-DH), 6-phosphogluconate dehydrogenase (6PG-DH), alanine aminotransferase (ALT) and aspartate aminotransferase (AST) in the liver of gilthead sea bream fed, starved and subsequently refed on diets of different composition $\dagger$

(Mean values and standard deviations for three fish)

\begin{tabular}{|c|c|c|c|c|c|c|c|c|c|c|c|}
\hline \multirow[b]{3}{*}{ Enzyme } & \multirow[b]{3}{*}{ Diet } & \multicolumn{10}{|c|}{ Condition } \\
\hline & & \multicolumn{2}{|c|}{ Fed } & \multicolumn{2}{|c|}{ Starved $19 d$} & \multicolumn{2}{|c|}{ Refed $1 \mathrm{~d}$} & \multicolumn{2}{|c|}{ Refed 3d } & \multicolumn{2}{|c|}{ Refed $8 d$} \\
\hline & & Mean & SD & Mean & SD & Mean & SD & Mean & SD & Mean & $\mathrm{SD}$ \\
\hline PFK-1 & $\begin{array}{l}1 \\
2 \\
3 \\
4 \\
5\end{array}$ & $\begin{array}{l}30 \cdot 7^{\mathrm{a}} \\
36 \cdot 0^{\mathrm{ab}} \\
33 \cdot 0^{\mathrm{a}} \\
42 \cdot 5^{\mathrm{ab}} \\
49 \cdot 2^{\mathrm{b}}\end{array}$ & $\begin{array}{r}2.4 \\
4.4 \\
3.6 \\
3.4 \\
15.2\end{array}$ & $\begin{array}{l}8 \cdot 8^{\star *} \\
8 \cdot 3^{* \star} \\
8 \cdot 7^{\star \star} \\
9 \cdot 3^{\star *} \\
6 \cdot 1^{\star *}\end{array}$ & $\begin{array}{l}3 \cdot 8 \\
6 \cdot 0 \\
2 \cdot 3 \\
0 \cdot 7 \\
1 \cdot 0\end{array}$ & $\begin{array}{l}23 \cdot 0^{\mathrm{a} *} \\
32 \cdot 3^{\mathrm{ab}} \\
30 \cdot 6^{\mathrm{ab}} \\
30 \cdot 8^{\mathrm{ab}} \\
37 \cdot 0^{\mathrm{b}}\end{array}$ & $\begin{array}{l}1 \cdot 3 \\
2 \cdot 7 \\
4 \cdot 0 \\
8 \cdot 6 \\
6 \cdot 3\end{array}$ & $\begin{array}{l}34 \cdot 3^{\mathrm{ab}} \\
32 \cdot 6^{\mathrm{ab}} \\
31 \cdot 4^{\mathrm{a}} \\
38 \cdot 8^{\mathrm{b}} \\
39 \cdot 1^{\mathrm{b}}\end{array}$ & $\begin{array}{l}4 \cdot 5 \\
4 \cdot 6 \\
2 \cdot 7 \\
2 \cdot 6 \\
2 \cdot 9\end{array}$ & $\begin{array}{l}30 \cdot 7^{\mathrm{a}} \\
33 \cdot 3^{\mathrm{a}} \\
41.5^{\mathrm{ab} *} \\
53 \cdot 6^{\mathrm{bc}} \\
65 \cdot 5^{\mathrm{c} *}\end{array}$ & $\begin{array}{c}2.2 \\
10 \\
5 \cdot 6 \\
9.9 \\
17\end{array}$ \\
\hline PK & $\begin{array}{l}1 \\
2 \\
3 \\
4 \\
5\end{array}$ & $\begin{array}{l}300^{a} \\
382^{a} \\
513^{b} \\
784^{c} \\
567^{b}\end{array}$ & $\begin{array}{l}33 \\
51 \\
91 \\
40 \\
85\end{array}$ & $\begin{array}{l}197^{a b * *} \\
146^{a * \star} \\
231^{a b * *} \\
305^{b \star *} \\
242^{a b * *}\end{array}$ & $\begin{array}{r}6 \\
21 \\
101 \\
43 \\
68\end{array}$ & $\begin{array}{l}205^{\mathrm{a} * *} \\
297^{\mathrm{b*}} \\
327^{\mathrm{b*}} \\
426^{\mathrm{c} * \star} \\
360^{\mathrm{bc**}}\end{array}$ & $\begin{array}{l}38 \\
29 \\
66 \\
34 \\
37\end{array}$ & $\begin{array}{l}268^{\mathrm{a}} \\
283^{\mathrm{a} *} \\
329^{\mathrm{ab} *} \\
427^{\mathrm{c} * *} \\
384^{\mathrm{bc*}}\end{array}$ & $\begin{array}{l}36 \\
25 \\
33 \\
33 \\
31\end{array}$ & $\begin{array}{l}273^{\mathrm{a}} \\
338^{\mathrm{ab}} \\
392^{\mathrm{bc}} \\
486^{\mathrm{cd} \star \star} \\
524^{\mathrm{d}}\end{array}$ & $\begin{array}{l}34 \\
45 \\
31 \\
36 \\
84\end{array}$ \\
\hline FBPase-1 & $\begin{array}{l}1 \\
2 \\
3 \\
4 \\
5\end{array}$ & $\begin{array}{l}123 \\
119 \\
144 \\
140 \\
142\end{array}$ & $\begin{array}{l}10 \\
13 \\
11 \\
29 \\
29\end{array}$ & $\begin{array}{l}137^{\mathrm{a}} \\
219^{\mathrm{c} * \star} \\
193^{\mathrm{bc*}} \\
171^{\mathrm{ab}} \\
185^{\mathrm{bc}}\end{array}$ & $\begin{array}{l}34(n 5) \\
12 \\
6 \\
34(n 5) \\
23\end{array}$ & $\begin{array}{l}156^{\mathrm{a}} \\
151^{\mathrm{a}} \\
211^{\mathrm{b} *} \\
168^{\mathrm{a}} \\
164^{\mathrm{a}}\end{array}$ & $\begin{array}{l}2 \cdot 3 \\
16 \\
42 \\
21 \\
13\end{array}$ & $\begin{array}{l}194^{\mathrm{ab} *} \\
157^{\mathrm{ab} *} \\
145^{\mathrm{a}} \\
207^{\mathrm{b} *} \\
156^{\mathrm{ab}}\end{array}$ & $\begin{array}{c}35 \\
26 \\
21 \\
36 \\
6 \cdot 1\end{array}$ & $\begin{array}{l}178^{\star} \\
180^{\star *} \\
194 \\
207^{\star} \\
190\end{array}$ & $\begin{array}{l}8 \cdot 9 \\
16 \\
41(n 4) \\
9 \cdot 1 \\
83\end{array}$ \\
\hline G6P-DH & $\begin{array}{l}1 \\
2 \\
3 \\
4 \\
5\end{array}$ & $\begin{array}{l}138^{a} \\
132^{a} \\
201^{b c} \\
163^{a b} \\
246^{c}\end{array}$ & $\begin{array}{c}50 \\
34 \\
8 \cdot 0 \\
3 \cdot 0 \\
17\end{array}$ & $\begin{array}{l}84^{\star} \\
113 \\
114^{\star \star} \\
116^{\star \star} \\
105^{\star \star}\end{array}$ & $\begin{array}{r}10 \\
17 \\
31 \\
13 \\
8\end{array}$ & $\begin{array}{c}86^{a *} \\
117^{a b} \\
118^{a b \star *} \\
117^{a b *} \\
126^{b \star *}\end{array}$ & $\begin{array}{c}13 \\
9.9 \\
6 \cdot 9 \\
9 \cdot 9 \\
19\end{array}$ & $\begin{array}{l}145 \\
134 \\
120^{\star \star} \\
118^{*} \\
122^{\star *}\end{array}$ & $\begin{array}{c}32 \\
6 \cdot 1 \\
12 \\
21 \\
6 \cdot 3\end{array}$ & $\begin{array}{l}187^{\mathrm{b*}} \\
124^{\mathrm{a}} \\
209^{\mathrm{bc}} \\
153^{\mathrm{ab}} \\
222^{\mathrm{c}}\end{array}$ & $\begin{array}{l}24 \\
41 \\
33 \\
25 \\
64\end{array}$ \\
\hline 6PG-DH & $\begin{array}{l}1 \\
2 \\
3 \\
4 \\
5\end{array}$ & $\begin{array}{l}24 \cdot 4^{\mathrm{a}} \\
34 \cdot 8^{\mathrm{ab}} \\
44 \cdot 5^{\mathrm{b}} \\
40 \cdot 3^{\mathrm{ab}} \\
44 \cdot 6^{\mathrm{b}}\end{array}$ & $\begin{array}{c}4.0 \\
12 \\
11 \\
6.5 \\
1.4\end{array}$ & $\begin{array}{l}13 \cdot 8^{a} \\
28 \cdot 2^{b} \\
25 \cdot 1^{b * *} \\
29 \cdot 6^{b *} \\
28 \cdot 5^{b * *}\end{array}$ & $\begin{array}{l}2 \cdot 3 \\
1.2 \\
4.0 \\
3 \cdot 3 \\
4.9\end{array}$ & $\begin{array}{l}19 \cdot 3^{a} \\
23 \cdot 3^{a b} \\
22 \cdot 5^{a b \star \star} \\
24 \cdot 6^{a b \star \star} \\
26 \cdot 1^{b \star \star}\end{array}$ & $\begin{array}{l}3.2 \\
2.5 \\
2 \cdot 3 \\
2 \cdot 3 \\
4 \cdot 9\end{array}$ & $\begin{array}{l}28 \cdot 6 \\
26 \cdot 9 \\
24 \cdot 0^{\star *} \\
30 \cdot 3^{*} \\
28 \cdot 1^{\star *}\end{array}$ & $\begin{array}{l}10 \\
0.8 \\
4.4 \\
3.6 \\
1.7\end{array}$ & $\begin{array}{l}29 \cdot 9^{\mathrm{a}} \\
27 \cdot 6^{\mathrm{a}} \\
37 \cdot 6^{\mathrm{a}} \\
34 \cdot 4^{\mathrm{a}} \\
56 \cdot 3^{\mathrm{b}}\end{array}$ & $\begin{array}{l}0.6 \\
8.0 \\
2 \cdot 8 \\
5 \cdot 1 \\
2.3\end{array}$ \\
\hline ALT & $\begin{array}{l}1 \\
2 \\
3 \\
4 \\
5\end{array}$ & $\begin{array}{c}1085^{\mathrm{b}} \\
1040^{\mathrm{b}} \\
1154^{\mathrm{b}} \\
671^{\mathrm{a}} \\
695^{\mathrm{c}}\end{array}$ & $\begin{array}{r}179 \\
109 \\
81 \\
77 \\
198\end{array}$ & $\begin{array}{l}575^{a b * *} \\
567^{a b * *} \\
858^{b *} \\
467^{a * *} \\
526^{a b}\end{array}$ & $\begin{array}{r}19 \\
8 \\
274 \\
29 \\
16\end{array}$ & $\begin{array}{l}847^{\mathrm{b}} \\
748^{\mathrm{b} * *} \\
867^{\mathrm{b}} \\
521^{\mathrm{a} *} \\
490^{\mathrm{a}}\end{array}$ & $\begin{array}{r}49 \\
73 \\
184 \\
79 \\
92\end{array}$ & $\begin{array}{l}1058^{\mathrm{c}} \\
795^{\mathrm{b} *} \\
796^{\mathrm{b}} \\
471^{\mathrm{a} \star \star} \\
490^{\mathrm{a}}\end{array}$ & $\begin{array}{r}132 \\
112 \\
35 \\
78 \\
63\end{array}$ & $\begin{array}{c}1408^{\mathrm{c} *} \\
799^{\mathrm{a} *} \\
1109^{\mathrm{b}} \\
526^{\mathrm{a} *} \\
538^{\mathrm{a}}\end{array}$ & $\begin{array}{r}186 \\
74 \\
204 \\
36 \\
50\end{array}$ \\
\hline AST & $\begin{array}{l}1 \\
2 \\
3 \\
4 \\
5\end{array}$ & $\begin{array}{l}1745^{\mathrm{b}} \\
1489^{\mathrm{a}} \\
1693^{\mathrm{b}} \\
1387^{\mathrm{a}} \\
1567^{\mathrm{ab}}\end{array}$ & $\begin{array}{r}59 \\
19 \\
139 \\
156 \\
20\end{array}$ & $\begin{array}{l}1838 \\
1804^{\star *} \\
1972 \\
2014^{\star *} \\
1833\end{array}$ & $\begin{array}{r}29 \\
140 \\
405 \\
338 \\
245\end{array}$ & $\begin{array}{l}1457 \\
1608 \\
1631 \\
1512 \\
1341\end{array}$ & $\begin{array}{r}142 \\
68 \\
116 \\
106 \\
284\end{array}$ & $\begin{array}{l}1967^{\mathrm{c}} \\
1498^{\mathrm{b}} \\
1597^{\mathrm{b}} \\
1120^{\mathrm{a}} \\
1076^{\mathrm{a} * \star}\end{array}$ & $\begin{array}{r}138 \\
58 \\
130 \\
21 \\
20\end{array}$ & $\begin{array}{l}1786^{\mathrm{b}} \\
1655^{\mathrm{ab} *} \\
1780^{\mathrm{b}} \\
1312^{\mathrm{a}} \\
1544^{\mathrm{ab}}\end{array}$ & $\begin{array}{r}279 \\
26 \\
204 \\
30 \\
96\end{array}$ \\
\hline
\end{tabular}

a,b,c Mean values within a column not sharing a common superscript letter were significantly different, $P<0.05$.

Mean values were significantly different from those for the corresponding fed fish: ${ }^{\star} P<0.05,{ }^{\star \star} P<0.01$.

†For details of diets and procedures, see Table 1 and pp. 224-225.

Starvation resulted in a significant increase in FBPase-1 activity in the fish previously fed on diets 2 and 3 , and a tendency to increase was observed in the other groups studied. After $8 \mathrm{~d}$ of refeeding the values remained elevated, regardless of the diet.

Moreover, as the carbohydrate content of the diets increased, higher PFK-1:FBPase-1 and PK:FBPase-1 ratios were observed. For example, at the end of the refeeding period PFK-1:FBPase-1 values rose from 0.17 for diet 1 to 0.26 and 0.34 for diets 4 and 5 respectively. After $8 \mathrm{~d}$ of refeeding the PK : FBPase- 1 ratio rose from 1.53 for diet 1 to 2.35 and 2.76 for diets 4 and 5 respectively (Table 3).

In fish fed on high-protein diets (diets 1-3) for $18 \mathrm{~d}$, ALT values were significantly higher than in those fish fed on low-protein diets (4 and 5) (Table 3). Starvation for 19d caused a decrease in the enzyme activity in all groups of fish studied, particularly in those previously fed on high-protein, low-carbohydrate diets. Refeeding fish for $8 \mathrm{~d}$ on high-protein, low-carbohydrate diets promoted high ALT levels except for diet 2. However, refeeding on low-protein, high-carbohydrate diets (diets 4 and 5) produced levels of enzyme activity slightly below those previously found in the liver of fed fish.

In contrast, a slight increase in AST enzyme activity was observed in all groups of starved fish, with differences being significant for diets 2 and 4 (Table 3). The highest AST enzyme activity was found in fish fed on the highest protein, low-carbohydrate diet (diet 1), as for ALT. In addition, the highest AST values were observed when fish were fed on the diets with the lower energy content (1, 3 and 5).

\section{Effect of ration size}

Four groups of fish were refed on different quantities of diet after a starvation period of $8 \mathrm{~d}$. Diet 3, with a composition close to that of a standard commercial diet, was provided at 


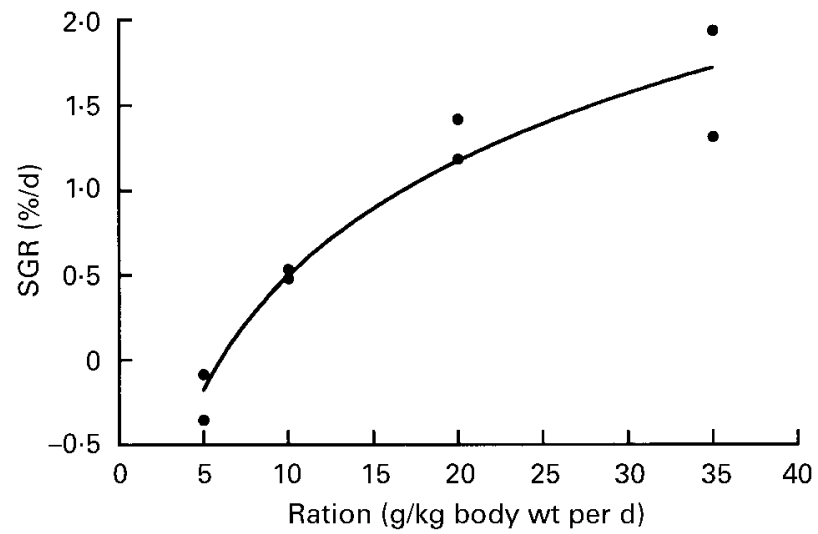

Fig. 2. Specific growth rate (SGR) of gilthead sea bream as a function of ration size. Each point represents the mean growth rate (as \% SGR per d) of the fish per aquarium. Two aquaria were used for each treatment (thirty-six to thirty-eight fish per aquarium). For procedures to calculate SGR, see p. 225. The solid line indicates the fitted logarithmic relationship, constructed by regression analysis $(y=$ $0.50+2.25 \log x ; r 0.96)$.

$5,10,20$ and $35 \mathrm{~g} / \mathrm{kg}$ BW per d, respectively. After $22 \mathrm{~d}$ of refeeding the $\mathrm{BW}$ and the LSI correlated well with the quantity of diet provided. Moreover, fish refed on the $5 \mathrm{~g} / \mathrm{kg}$ BW ration size showed negative growth and their LSI values were significantly lower than in any other group (Fig. 1(b)). The specific growth rate of the fish was also calculated, and Fig. 2 shows that a good correlation between specific growth rate and ration size could be established. Meanwhile at 20 and $35 \mathrm{~g} / \mathrm{kg}$ BW significant increases in BW were found; fish fed at $5 \mathrm{~g} / \mathrm{kg}$ BW lost weight compared with starved animals.

After $1 \mathrm{~d}$ of refeeding, liver glycogen was significantly higher in fish fed at 20 and $35 \mathrm{~g} / \mathrm{kg} \mathrm{BW}$ per d than in fish starved or fed on 5 and $10 \mathrm{~g} / \mathrm{kg} \mathrm{BW}$ rations. As might be expected, after $22 \mathrm{~d}$ of refeeding, the lowest values were found in fish refed at $5 \mathrm{~g} / \mathrm{kg} \mathrm{BW}$, and those refed at $20 \mathrm{~g} / \mathrm{kg}$ BW showed the highest values, although these were not significantly different from those obtained with 10 and $35 \mathrm{~g} /$ $\mathrm{kg}$ (Table 4).

PFK-1, PK, G6P-DH, 6PG-DH and ALT enzyme activities were all positively correlated with ration size after $22 \mathrm{~d}$ of refeeding whereas a negative correlation was found for FBPase-1. Fig. 3 shows regression analysis corresponding to PFK-1, PK, FBPase-1 and G6P-DH activities. PFK-1 and PK activity values showed a certain tendency to plateau at a ration size of $20 \mathrm{~g} / \mathrm{kg} \mathrm{BW}$, as for 6PG-DH and ALT activities (results not shown). PFK-1 and ALT activities, in fish refed for $22 \mathrm{~d}$ at $5 \mathrm{~g} / \mathrm{kg} \mathrm{BW}$, were not significantly higher than those observed in the starved fish, while the PK, G6P-DH, 6PG-DH and AST values were even lower than those in the starved fish. FBPase-1 activity was similar to that seen in starved fish (Table 5).

At 8 and $22 \mathrm{~d}$ of refeeding, a clear relationship was found between PFK-1 : FBPase-1 and PK : FBPase-1 ratios and the quantity of diet supplied. Thus, at $22 \mathrm{~d}$ PFK-1 : FBPase-1 was 0.12 for a ration size of $5 \mathrm{~g} / \mathrm{kg} \mathrm{BW}$ and 0.34 for $35 \mathrm{~g} / \mathrm{kg}$ BW, and similarly the PK: FBPase-1 value changed from 0.98 to 3.3 (Table 5). In addition, in fish fed at $5 \mathrm{~g} / \mathrm{kg} \mathrm{BW}$ both values were similar to those of starved fish.

AST activity was very variable and it was difficult to compare between starved and refed fish or between fish fed at different ration sizes. However, it is clear that there was a strong decrease in enzyme activity after only $1 \mathrm{~d}$ of refeeding (significant in the case of 5 and $35 \mathrm{~g} / \mathrm{kg} \mathrm{BW}$ ration sizes), with lower values being maintained afterwards with minor oscillations. Even though AST was lower in fish refed for $22 \mathrm{~d}$ compared with starved fish, no significant differences were found in relation to the ration size (Table 5).

\section{Discussion}

Nutritional regulation of key enzyme activities of glycolysis-gluconeogenesis, the pentose phosphate pathway and amino acid metabolism by diet composition

In the present study the activities of PFK-1 and PK, both key enzymes in the regulation of the glycolysis, decreased after prolonged starvation, while FBPase-1 activity seemed to increase. We have previously observed that starvation promotes a decrease in the hepatic content of fructose 2,6bisphosphate in S. aurata (García de Frutos et al. 1990, 1991; Metón et al. 1995, 1999; Metón, 1996). The fall in the frutose 2,6-bisphosphate levels halts stimulation of PFK-1 and allows the increase in FBPase-1 (Bonamusa et al. 1992). This process shows analogies with that found in mammals (Hue \& Rider, 1987; Baanante et al. 1991; Pilkis \& Claus, 1991).

The present results indicate that after refeeding the starved fish with different types of diet, levels of glycogen in the liver recovered in a gradual manner within 3-8d, with the highest values found in fish fed on high-carbohydrate, low-protein diets. On the basis of enzyme activity measurements, gluconeogenesis seems to predominate over glycolysis in fish refed for $1-3 d$ (Table 3 ), suggesting that the initial recovery of glycogen in the liver of refed $S$. aurata may also derive from three-C compounds (Baanante et al. 1991). In favour of this possibility, French et al. (1981) and Cowey \& Walton (1989), indicated that the low carbohydrate and high protein content of the natural fish diet makes the synthesis of glucose and glycogen from non-carbohydrate compounds, such as lactate, amino acids and glycerol, more feasible.

In the present study, the highest hepatic PFK-1 and PK activities were found in $S$. aurata fed with high-carbohydrate, low-protein diets (diets 4 and 5). Moreover, after $8 \mathrm{~d}$ of refeeding the PFK-1 : FBPase-1 ratio showed differences between diets, with values ranging from 0.17 for fish fed on diet 1 to $0 \cdot 34$ for those fed on diet 5. The PK: FBPase-1 values also ranged from 1.53 for diet 1 to 2.75 for diet 5 (Table 3 ). The increased ratio values of glycolytic enzymes (PFK-1 and PK) over FBPase-1 gluconeogenic enzyme activity would suggest an increase in glycolysis and thus metabolic adaptation to high-carbohydrate, low-protein diets. In other fish, such as the European eel (Anguilla anguilla), the administration of high-carbohydrate diets also increases the liver PK activity (Suárez et al. 1995). This process is related to the increase in the production of pyruvate, which together with NADP, is a precursor for biosynthesis of fatty acids. The same is found in the rat, in which, in addition to increased PFK-1 and PK liver activities, the respective mRNA increase following feeding on high-carbohydrate diets (Noguchi et al. 1985; Gehnrich et al. 1988). In contrast, no nutritional regulation of PK 
Table 4. Liver glycogen levels ( $\mathrm{mg} / \mathrm{g}$ fresh liver) in gilthead sea bream refed on diet 3 (see Table 1) at 5, 10, 20 and $35 \mathrm{~g} / \mathrm{kg}$ body weight for $1,3,8$ or $22 \mathrm{~d}$ after an $8 \mathrm{~d}$ period of starvationt

(Mean values and standard deviations for four fish)

\begin{tabular}{|c|c|c|c|c|c|c|c|c|c|c|}
\hline \multicolumn{2}{|c|}{ Starved $8 d$} & $\begin{array}{l}\text { Ration size } \\
\text { (g/kg body wt) }\end{array}$ & \multicolumn{2}{|c|}{ Refed 1d } & \multicolumn{2}{|c|}{ Refed 3d } & \multicolumn{2}{|c|}{ Ref $8 d$} & \multicolumn{2}{|c|}{ Refed $22 \mathrm{~d}$} \\
\hline 2 & 1 & $\begin{array}{r}5 \\
10 \\
20 \\
35\end{array}$ & $\begin{array}{l}11^{\mathrm{a}} \\
12^{\mathrm{a}} \\
55^{\mathrm{b} * *} \\
71^{\mathrm{b**}}\end{array}$ & $\begin{array}{r}9 \\
13 \\
15 \\
19\end{array}$ & $\begin{array}{l}49^{a \star \star} \\
53^{a \star \star} \\
75^{a \star \star} \\
69^{a \star \star}\end{array}$ & $\begin{array}{l}18 \\
22 \\
19 \\
27(n 6)\end{array}$ & $\begin{array}{r}30^{a *} \\
68^{b * *} \\
109^{\mathrm{c} * \star} \\
76^{\mathrm{b} * \star}\end{array}$ & $\begin{array}{l}10 \\
12 \\
13 \\
29(n 5)\end{array}$ & $\begin{array}{c}21^{\mathrm{a}} \\
92^{\mathrm{b**}} \\
128^{\mathrm{b**}} \\
102^{\mathrm{b**}}\end{array}$ & $\begin{array}{l}18 \\
13 \\
28(n 5) \\
38(n 6)\end{array}$ \\
\hline
\end{tabular}

$\overline{\mathrm{a}, \mathrm{b}, \mathrm{c}}$ Mean values within a column not sharing a common superscript letter were significantly different, $P<0.05$.

Mean values were significantly different from that for starved fish: ${ }^{\star} P<0.05,{ }^{\star \star} P<0.01$.

†For details of procedures, see pp. 224-225.

activity has been observed in rainbow trout (Salmo gairdneri) (Guderley \& Cardenas, 1980; Hilton \& Atkinson, 1982) nor in the American eel (Anguilla rostrata) (Roberts \& Anderson, 1985). High-protein diets promoted a decrease in liver PFK-1 in rainbow trout (Fideu et al. 1983), as we observed in S. aurata. Besides, Cowey et al. $(1977 a, b)$ reported a stimulation of gluconeogenesis through an increase in FBPase-1 enzyme activity in rainbow trout fed on highprotein diets. In the European eel, high-carbohydrate diets promoted a decrease in the rate of gluconeogenesis (Suárez et al. 1995).

In fish, knowledge of the regulation of the pentose
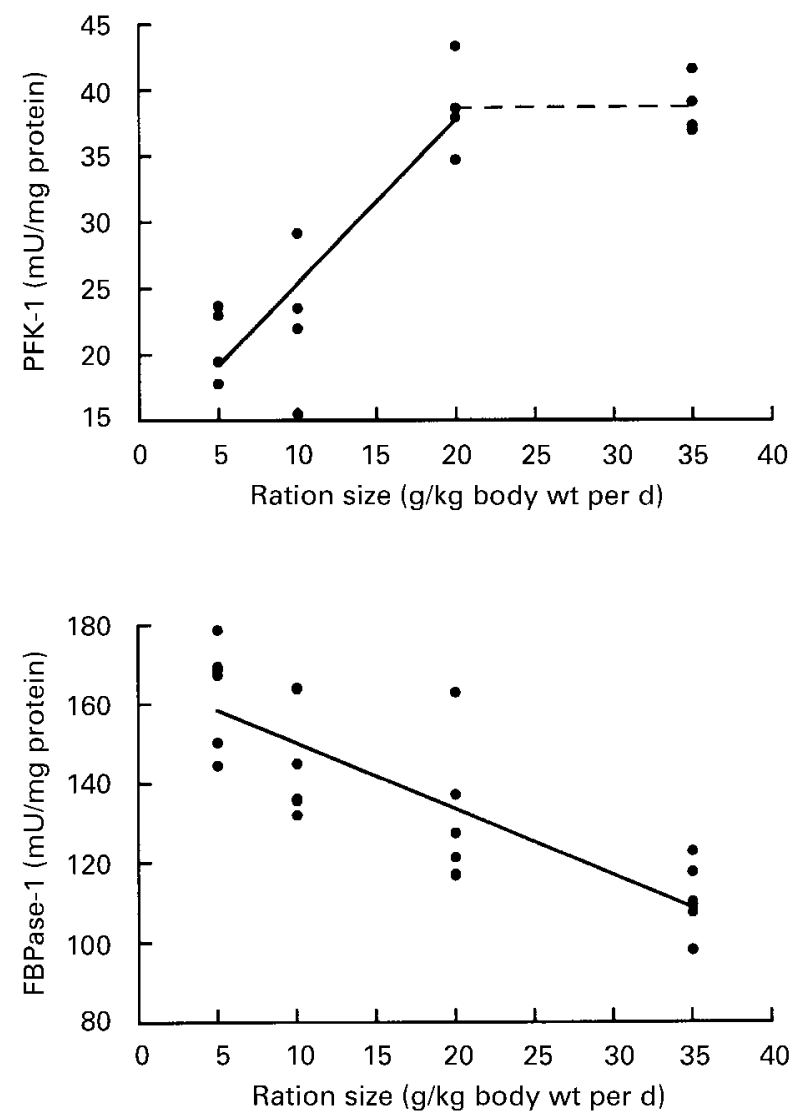

phosphate pathway is limited. Nevertheless it is clear that this pathway plays a key role in glucose utilization (Christiansen \& Klungsøyr, 1987; Cowey \& Walton, 1989). Lipids appear to be the main energy source in teleost fish (Cornell et al. 1986). The activities of enzymes that control the pentose phosphate pathway, G6P-DH and 6PG-DH, decreased in starved $S$. aurata (Table 3), as observed in Salvelinus fontinalus (Yamauchi et al. 1975) and rainbow trout (Barroso et al. 1993). Moreover, our results indicate that refeeding promoted a gradual recovery of both G6P-DH and 6PG-DH activities, depending on the carbohydrate content of the diet. This indicates that glucose may be
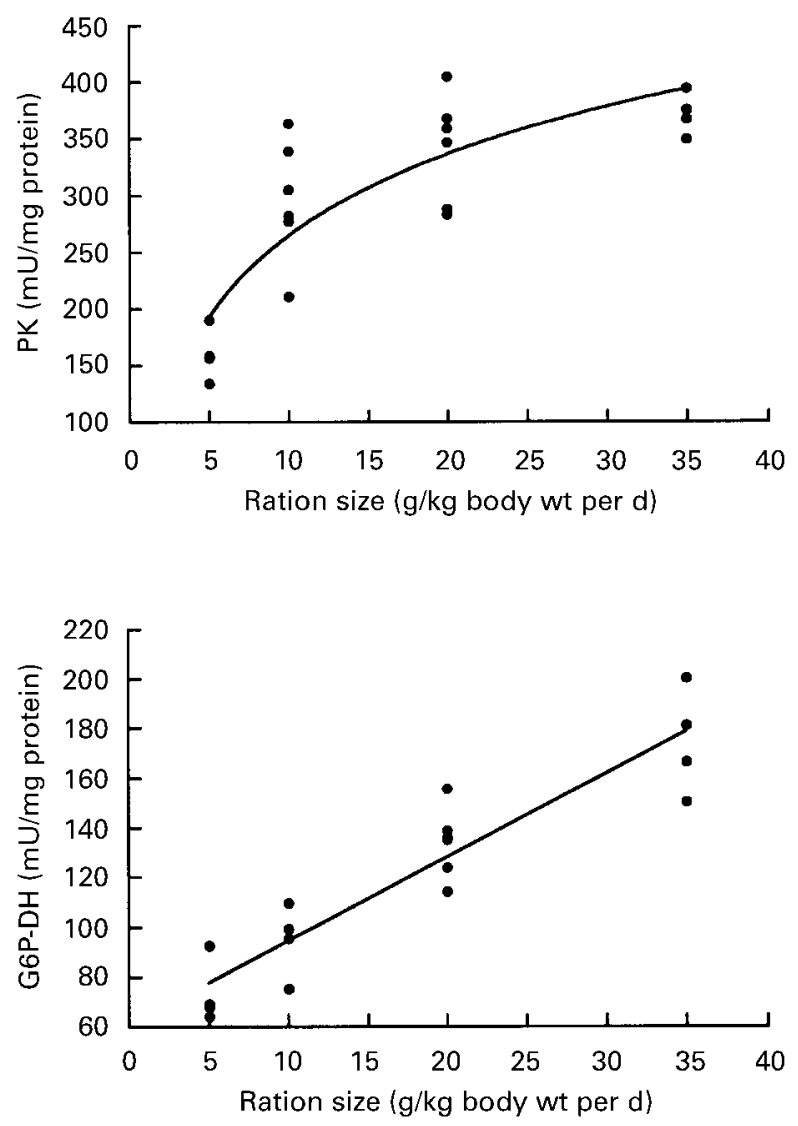

Fig. 3. Relationship between hepatic enzyme activity and ration size in gilthead sea bream. Each point represents the liver enzyme activity of an individual fish after refeeding for $22 \mathrm{~d}$ at $5,10,20$ or $35 \mathrm{~g} / \mathrm{kg}$ body weight per $\mathrm{d}$ with diet 3. PFK-1, 6-phosphofructo 1-kinase; PK, pyruvate kinase; FBPase-1, fructose-1,6-bisphophatase; G6P-DH, glucose-6-phosphate dehydrogenase. For details of procedures, see pp. 224-225. Linear and logarithmic relationships were tested using regression analysis. PFK-1, $(-) y=12.963+12.368 x, R 0.88 ;(--) y=38.492+0.066 x, R 0.02 ; \mathrm{PK}(-) y=$ $264.78+237.4 \log (x), R$ 0.838; FBPase-1, (-) $y=166.58+-16.502 x, R$ 0.821; G6P-DH, (-) $y=61.195+33.609 x, R 0.928$. 
used to provide NADPH for lipogenesis in S. aurata, as reported for other fish species (Likimani \& Wilson, 1982; Shimeno et al. 1993; Suárez et al. 1995). Furthermore, at equivalent protein levels supplied, partial replacement of lipid by carbohydrate in the diet (diet 2 compared with diet 3 , and diet 4 compared with diet 5) resulted in increased G6P-DH and 6PG-DH activity values. Likewise, activity of the rat hepatic G6P-DH, mRNA levels and gene transcription are promoted by high-protein, low-lipid diets and also by high-carbohydrate diets. In addition, both G6P-DH enzyme activity and mRNA levels decrease following starvation, and recover their normal levels after refeeding (Iritani, 1992; Towle et al. 1997; Stabile et al. 1998). As in S. aurata, the channel catfish (Ictalurus punctatus) fed on high-carbohydrate diets, showed increased liver G6P-DH and 6PG-DH enzyme activities (Likimani \& Wilson, 1982). In contrast both activities were found to be decreased in coho salmon (Oncorhynchus kisutch) (Lin et al. 1977).

It appears that carnivorous fish make more efficient use of protein than carbohydrates. However, the fact that $S$. aurata fed on high-carbohydrate, low-protein diets showed stimulation of key liver enzymes for glycolysis and the pentose phosphate pathway suggests its ability to utilize highcarbohydrate diets and thus spare protein.

ALT and AST enzyme activities are quantitatively the most important aminotransferases in the teleostean fish liver (Cowey \& Walton, 1989). We found that ALT activity decreased following starvation, whereas AST activity showed a slight tendency to increase. The effect of starvation on ALT and AST activities in other fish species is variable, as either increases or no changes after starvation have been reported (Moon \& Johnston, 1981; Cowey \& Walton, 1989; Kim et al. 1992; Fynn-Aikins et al. 1995). The increase in AST after starvation appears to indicate its more prominent role in protein mobilization compared with ALT in S. aurata. The increase observed in liver ALT when the fish were fed on high-protein diets may denote an efficient use of the dietary amino acids either for growth or as a substrate for gluconeogenesis. As for ALT, the highest AST enzyme activity was found in fish fed on the highest protein, low-carbohydrate diet (diet 1) or in fish fed on diets of the lowest energy content $(1,3$ and 5). In Atlantic salmon (Salmo salar), Fynn-Aikins et al. (1995) found that AST was not dependent on the type of energy source supplied to fish, while high-protein diets

Table 5. Activities (mU/mg protein) of 6-phosphofructo 1-kinase (PFK-1), pyruvate kinase (PK), fructose-1,6-bisphosphatase (FBPase-1), glucose-6-phosphate dehydrogenase (G6P-DH), 6-phosphogluconate dehydrogenase (6PG-DH), alanine aminotransferase (ALT) and aspartate aminotransferase (AST) in the liver of gilthead sea bream refed on diet 3 (see Table 1) at 5, 10, 20 and $35 \mathrm{~g} / \mathrm{kg}$ body weight for $1,3,8$ or $22 \mathrm{~d}$ after an $8 \mathrm{~d}$ period of starvation $\dagger$

(Mean values and standard deviations for three fish)

\begin{tabular}{|c|c|c|c|c|c|c|c|c|c|c|c|}
\hline \multirow[b]{3}{*}{ Enzyme } & & & \multirow{3}{*}{$\begin{array}{c}\text { Ration size } \\
\text { (g/kg } \\
\text { body wt) }\end{array}$} & \multicolumn{8}{|c|}{ Refed } \\
\hline & \multicolumn{2}{|c|}{ Starved $8 d$} & & \multicolumn{2}{|c|}{$1 d$} & \multicolumn{2}{|c|}{$3 d$} & \multicolumn{2}{|c|}{$8 d$} & \multicolumn{2}{|c|}{$22 d$} \\
\hline & Mean & SD & & Mean & $\mathrm{SD}$ & Mean & SD & Mean & SD & Mean & SD \\
\hline FBPase-1 & 162 & 19 & $\begin{array}{r}5 \\
10 \\
20 \\
35\end{array}$ & $\begin{array}{l}153^{\mathrm{ab}} \\
156^{\mathrm{ab}} \\
160^{\mathrm{b}} \\
130^{\mathrm{a} *}\end{array}$ & $\begin{array}{l}12 \\
17 \\
17 \\
18\end{array}$ & $\begin{array}{l}100^{a \star *} \\
106^{a \star *} \\
156^{\mathrm{b}} \\
149^{\mathrm{b}}\end{array}$ & $\begin{array}{l}14 \\
14(n 6) \\
19 \\
11\end{array}$ & $\begin{array}{c}130^{\mathrm{b} *} \\
95^{\mathrm{a} * \star} \\
97^{\mathrm{a} *} \\
121^{\mathrm{ab* \star}}\end{array}$ & $\begin{array}{l}6 \\
10 \\
25(n 7) \\
24(n 6)\end{array}$ & $\begin{array}{l}162^{\mathrm{a}} \\
146^{\mathrm{ab}} \\
131^{\mathrm{b} * \star} \\
111^{\mathrm{c} * \star}\end{array}$ & $\begin{array}{r}13(n 6) \\
15(n 6) \\
18(n 6) \\
9(n 6)\end{array}$ \\
\hline 6PG-DH & 35 & 2 & $\begin{array}{r}5 \\
10 \\
20 \\
35\end{array}$ & $\begin{array}{l}25^{a * *} \\
26^{a * *} \\
34^{\mathrm{b}} \\
32^{\mathrm{b}}\end{array}$ & $\begin{array}{l}0 \cdot 2 \\
4 \\
2 \\
3\end{array}$ & $\begin{array}{l}29 \\
29 \\
29 \\
46\end{array}$ & $\begin{array}{l}6 \\
5 \\
6 \\
3(n 6)\end{array}$ & $\begin{array}{l}29 \\
28 \\
41 \\
36\end{array}$ & $\begin{array}{r}5 \\
6 \\
13 \\
8\end{array}$ & $\begin{array}{l}24^{\mathrm{a*}} \\
28^{\mathrm{ab}} \\
38^{\mathrm{b}} \\
38^{\mathrm{b}}\end{array}$ & $\begin{array}{l}5 \\
4 \\
10(n 7) \\
9(n 6)\end{array}$ \\
\hline ALT & 342 & 106 & $\begin{array}{r}5 \\
10 \\
20 \\
35\end{array}$ & $\begin{array}{l}570^{\mathrm{a} * *} \\
570^{\mathrm{b} * *} \\
427^{\mathrm{a}} \\
436^{\mathrm{ab}}\end{array}$ & $\begin{array}{r}115 \\
92 \\
52 \\
28\end{array}$ & $\begin{array}{l}472 \\
526^{\star} \\
511^{*} \\
452\end{array}$ & $\begin{array}{r}55 \\
78 \\
87 \\
133\end{array}$ & $\begin{array}{l}427^{\mathrm{a}} \\
580^{\mathrm{bc**}} \\
525^{\mathrm{ab} *} \\
671^{\mathrm{c} * \star}\end{array}$ & $\begin{array}{l}65 \\
97 \\
14 \\
43\end{array}$ & $\begin{array}{c}233^{\mathrm{a}} \\
629^{\mathrm{b*}} \\
1071^{\mathrm{c} * \star} \\
831^{\mathrm{bc*} *}\end{array}$ & $\begin{array}{r}43 \\
81 \\
236 \\
132\end{array}$ \\
\hline AST & 2218 & 344 & $\begin{array}{r}5 \\
10 \\
20 \\
35\end{array}$ & $\begin{array}{l}1515^{a b *} \\
2071^{b} \\
1663^{a b} \\
1433^{a *}\end{array}$ & $\begin{array}{l}459 \\
505 \\
223 \\
170\end{array}$ & $\begin{array}{l}2074^{\mathrm{b}} \\
1752^{\mathrm{ab*}} \\
1615^{\mathrm{a} * \star} \\
1846^{\mathrm{ab}}\end{array}$ & $\begin{array}{r}98 \\
206 \\
48 \\
358\end{array}$ & $\begin{array}{l}1539^{a \star *} \\
2049^{b} \\
1690^{a \star *} \\
1862^{a b}\end{array}$ & $\begin{array}{r}59 \\
238 \\
216 \\
169\end{array}$ & $\begin{array}{l}1438^{\star *} \\
1438^{*} \\
1891 \\
1502^{\star *}\end{array}$ & $\begin{array}{l}304 \\
102 \\
272 \\
195\end{array}$ \\
\hline
\end{tabular}

$\overline{a, b, c}$ Mean values within a column not sharing a common superscript letter were significantly different, $P<0.05$.

Mean values were significantly different from those for starved fish: ${ }^{*} P<0.05,{ }^{* *} P<0.01$.

† For details of procedures, see pp. 224-225. 
promoted stimulation of the liver ALT. Lupiáñez et al. (1989) also observed an increase in ALT activity in rainbow trout fed on high-protein diets. Both aminotransferases increase with the increase in the protein content of the diet in Mugil capito (Alexis \& Papaparaskeva-Papoutsoglou, 1986). However, no variation in aminotransferase activity resulting from highprotein diets has been reported in other fish (Nagai \& Ikeda, 1973a,b; Cowey \& Walton, 1989).

\section{Effect of energy restriction on key enzyme activities of glycolysis-gluconeogenesis, the pentose phosphate pathway and amino acid metabolism}

Restricted feeding resulted in a decreased LSI. S. aurata refed with a ration of $5 \mathrm{~g} / \mathrm{kg}$ BW showed similar values to those of starved fish, reflecting the low availability of nutrients for growth (Fig. 1).

The hepatic levels of glycogen also depended on ration size. After $22 \mathrm{~d}$ of refeeding, the glycogen content in the group fed on the $5 \mathrm{~g} / \mathrm{kg}$ BW ration was extremely low, although in all cases values were above those found in starved fish. On the other hand, the glycogen values observed in the group fed on the $20 \mathrm{~g} / \mathrm{kg} \mathrm{BW}$ ration were not significantly different from those of the group fed at $35 \mathrm{~g} / \mathrm{kg} \mathrm{BW}$. This suggests saturation of the stimulating effect over the synthesis of glycogen in the group of fish fed at $20 \mathrm{~g} / \mathrm{kg} \mathrm{BW}$ (Table 4).

We have previously observed that feeding $S$. aurata at $5 \mathrm{~g} / \mathrm{kg}$ BW promotes low levels of fructose 2,6-bisphosphate in the liver (Metón, 1996). This finding could at least partially explain the decrease in PFK-1 enzyme activity found in this group of fish, which together with the decrease in PK activity and the increase in the FBPase-1 activity, could lead to a rate of glycolysis-gluconeogenesis similar to that for starved fish.

In addition, the activity of the enzymes involved in the control of the pentose phosphate pathway, G6P-DH and 6PG-DH, decreased as a consequence of the energy restriction. After $22 \mathrm{~d}$ of refeeding at 5 and $10 \mathrm{~g} / \mathrm{kg} \mathrm{BW}, \mathrm{G} 6 \mathrm{P}-\mathrm{DH}$ activity was even lower than that in starved $S$. aurata. This may be related to the low availability of glucose from the diet to be derived as a substrate for the pentose phosphate pathway. Consequently, the biosynthetic capacity of fatty acids would also decrease. These findings are consistent with those found in rainbow trout (Bastrop et al. 1992), striped bass (Morone saxatilis) (Hung et al. 1993) and carp (Shimeno et al. 1997). Moreover, as food supplied to S. aurata increased to 20 or $35 \mathrm{~g} / \mathrm{kg} \mathrm{BW}$, the activity of these enzymes increased, which is consistent with long-term regulation by either dietary manipulation of food quantity or diet composition. In fact, the best correlation between ration size and enzyme activity was found for G6P-DH (Fig. 3).

After $22 \mathrm{~d}$ of refeeding the liver AST activity decreased, regardless of the ration size. In contrast, liver ALT enzyme activity showed a positive correlation with ration size. Refeeding at $5 \mathrm{~g} / \mathrm{kg}$ BW led to values similar to those obtained in starved $S$. aurata. Other ration sizes, mainly 20 and $35 \mathrm{~g} / \mathrm{kg} \mathrm{BW}$, led to increases in this enzyme activity. Thus, hepatic ALT appears to be more sensitive than AST to changes in ration size in $S$. aurata. Similarly, glutamate dehydrogenase (EC 1.4.1.2), another enzyme involved in amino acid catabolism, decreases under restricted protein and energy diets in the European eel (Suárez et al. 1995).

All data presented here indicate a high level of metabolic adaptation to both diet type and ration size. In particular, adaptation of enzyme activities to the consumption of a diet with high carbohydrate levels indicates that a carnivorous fish like $S$. aurata can tolerate partial substitution of protein by carbohydrate in the commercial diets supplied in culture.

The relationship between enzyme activities, ration size and growth suggests that the enzymes studied respond quickly to dietary manipulation and could be used as indicators of nutritional conditions and growth performance of cultured fish.

\section{Acknowledgements}

This study was supported by grants from CICYT (PTR910067) and DGICYT (PB93-0757, PB96-1488) from Ministerio de Educación y Ciencia (Spain). A. Caseras is recipient of a Predoctoral Fellowship from the M.E.C. of Spain.

\section{References}

Alexis MN \& Papaparaskeva-Papoutsoglou E (1986) Aminotransferase activity in the liver and white muscle of Mugil capito fed diets containing different levels of protein and carbohydrate. Comparative Biochemistry and Physiology 83B, 245-249.

Baanante IV, García de Frutos P, Bonamusa L \& Fernández F (1991) Regulation of fish glycolysis-gluconeogenesis. Role of fructose 2,6- $\mathrm{P}_{2}$ and PFK-2. Comparative Biochemistry and Physiology 100B, 11-17.

Barroso JB, García-Salguero L, Peragón J, de la Higuera M \& Lupiáñez JA (1993) Effects of long-term starvation on the NADPH production systems in several different tissues of rainbow trout (Oncorhynchus mykiss) In Fish Nutrition in Practice, pp. 333-338 [SJ Kaushik and P Luquet, editors]. Paris: INRA.

Bastrop R, Jurss K \& Wacke R (1992) Biochemical parameters as a measure of food availability and growth in immature rainbow trout (Oncorhynchus mykiss). Comparative Biochemistry and Physiology 102A, 151-161.

Bonamusa L, García de Frutos P, Fernández F \& Baanante IV (1989) Enzymes as indicators of nutritional conditions in the gilthead sea bream fish, Sparus aurata. In International Aquaculture Conference, Aquaculture Europe '89, p. 37 [R Billard and N De Pauw, editors]. Bredene, Belgium.

Bonamusa L, García de Frutos P, Fernández F \& Baanante IV (1992) Nutritional effects on key glycolytic-gluconeogenic enzyme activities and metabolite levels in the liver of the teleost fish Sparus aurata. Molecular Marine Biology and Biotechnology 1, $113-125$

Bradford MM (1976) A rapid and sensitive method for the quantitation of microgram quantities of protein utilizing the principle of protein-dye binding. Analytical Biochemistry 72, 248-254.

Brauge C, Medale F \& Corraze G (1994) Effects of dietary carbohydrate levels on growth, body composition and glycaemia in rainbow trout, Oncorhynchus mykiss, reared in seawater. Aquaculture 123, 109-120.

Christiansen DC \& Klungsøyr L (1987) Metabolic utilization of nutrients and the effects of insulin in fish. Comparative Biochemistry and Physiology 88B, 701-711.

Cornell NW, Stegelman JJ, Kerich MJ \& Woodwin BR (1986) Metabolite and enzyme contents of freeze-clamped liver of the marine fish Stenotomus chrysops. Comparative Biochemistry and Physiology 85B, 669-674.

Cowey CB, Higuera M \& Adron JW (1977a) The effect of dietary 
composition and of insulin on gluconeogenesis in rainbow trout (Salmo gairdneri). British Journal of Nutrition 38, 385-395.

Cowey CB, Knox D, Walton MJ \& Adron JW (1977b) The regulation of gluconeogenesis by diet and insulin in rainbow trout (Salmo gairdneri). British Journal of Nutrition 38, 463-470.

Cowey CB \& Walton MJ (1989) Intermediary metabolism. In Fish Nutrition, pp. 260-321 [JE Halver, editor]. San Diego, CA: Academic Press.

Fideu MD, Soler G \& Ruiz-Amil M (1983) Nutritional regulation of glycolysis in rainbow trout (Salmo gairdneri R.). Comparative Biochemistry and Physiology 74B, 795-799.

French CJ, Mommsen TP \& Hochachka PW (1981) Amino acid utilization in isolated hepatocytes from rainbow trout. European Journal of Biochemistry 113, 311-317.

Furuichi M \& Yone Y (1981) The utilization of carbohydrate by fishes. 3. Changes of blood-sugar and plasma-insulin levels of fishes in glucose-tolerance test. Bulletin of the Japanese Society of Scientific Fisheries 47, 761-764.

Fynn-Aikins K, Hughes SG \& Vandenberg GW (1995) Protein retention and liver aminotransferase activities in Atlantic salmon fed diets containing different energy sources. Comparative Biochemistry and Physiology 111A, 163-170.

García de Frutos P, Bonamusa L \& Baanante IV (1991) Metabolic changes in fish liver during the starved-to-fed transition. Comparative Biochemistry and Physiology 98A, 329-331.

García de Frutos P, Bonamusa L, Fernández F \& Baanante IV (1990) Fructose 2,6-bisphosphate in liver of Sparus aurata. Comparative Biochemistry and Physiology 96B, 63-65.

Gehnrich S, Gekakis N \& Sul HS (1988) Liver (b-type) phosphofructokinase mRNA. Journal of Biological Chemistry 263, 1175511759.

Guderley H \& Cardenas JM (1980) Pyruvate kinases of salmon: purification and comparison with the isozymes from birds and mammals. Journal of Experimental Zoology 211, 185-198.

Hilton JW \& Atkinson JL (1982) Response of rainbow trout (Salmo gairdneri) to increased levels of available carbohydrate in practical trout diets. British Journal of Nutrition 47, 597-607.

Hue L \& Rider MH (1987) Role of fructose 2,6-bisphosphate in the control of glycolysis in mammalian tissues. Biochemical Journal 245, 313-324.

Hung SSO, Conte FS \& Hallen EF (1993) Effects of feeding rates on growth, body composition and nutrient metabolism in striped bass (Morone saxatilis) fingerlings. Aquaculture 112, 349-361.

Iritani N (1992) Nutritional and hormonal regulation of lipogenicenzyme gene expression in rat liver. European Journal of Biochemistry 205, 433-442.

Kim KI, Grimshaw TW, Kayes TB \& Amundson CH (1992) Effect of fasting or feeding diets containing different levels of protein or amino acids on the activities of the liver amino acid-degrading enzymes and amino acid oxidation in rainbow trout (Oncorhynchus mykiss). Aquaculture 107, 89-105.

Likimani TA \& Wilson RP (1982) Effects of diet on lipogenic enzyme activities in channel catfish hepatic and adipose tissue. Journal of Nutrition 112, 112-117.

Lin H, Romsos DR, Tack PI \& Leveille GA (1977) Influence of dietary lipid on lipogenic enzyme activities in coho salmon (Oncorhynchus kisutch (Walbaum)). Journal of Nutrition 107, 846-854.

Lupiáñez JA, Sánchez-Lozano MJ, García-Rejón L \& de la Higuera M (1989) Long-term effect of a high-protein/non carbohydrate diet on the primary liver and kidney metabolism in rainbow trout (Salmo gairdneri). Aquaculture 79, 91-101.

Metón I (1996) Nutritional regulation of key enzymes in glycolysis-gluconeogenesis: expression of 6-phosphofructo 2kinase/fructose 2,6-bisphosphatase gene in liver of Sparus aurata, pp. 92-93, 114-115. Barcelona: Doctoral Thesis, University of Barcelona.

Metón I, Caseras A, Mediavilla D, Fernández F \& Baanante IV (1999) Molecular cloning of a cDNA encoding 6-phosphofructo-2-kinase/fructose-2,6-bisphosphatase from liver of Sparus aurata: nutritional regulation of enzyme expression. Biochimica et Biophysica Acta 1444, 153-165.

Metón I, Mediavilla D \& Baanante IV (1995) Automated assay for fructose 2,6-bisphosphate. Analytical Letters 28, 1919-1935.

Moon TW \& Johnston IA (1981) Amino acid transport and interconversions in tissues of freshly caught and food-deprived plaice, Pleuronectes platessa L. Journal of Fish Biology 19, 653-663.

Nagai M \& Ikeda S (1973a) Carbohydrate metabolism in fish -III. Effect of dietary composition on metabolism of glucose-U- ${ }^{14} \mathrm{C}$ and glutamate-U- ${ }^{14} \mathrm{C}$ in carp. Bulletin of the Japanese Society of Scientific Fisheries 38, 137-143.

Nagai M \& Ikeda S (1973b) Carbohydrate metabolism in fish-IV. Effect of dietary composition on metabolism of acetate- $\mathrm{U}_{-}{ }^{14} \mathrm{C}$ and L-alanine-U- ${ }^{14} \mathrm{C}$ in carp. Bulletin of the Japanese Society of Scientific Fisheries 39, 633-643.

Noguchi T, Inoue H \& Tanaka T (1985) Transcriptional and posttranscriptional regulation of L-type pyruvate kinase in diabetic rat liver by insulin and dietary fructose. Journal of Biological Chemistry 260, 14393-14397.

Pelletier D, Dutil JD, Blier P \& Guderley H (1994) Relation between growth rate and metabolic organization of white muscle, liver and digestive tract in cod, Gadus morhua. Journal of Comparative Physiology 164B, 179-190.

Pilkis SJ \& Claus TH (1991) Hepatic gluconeogenesis/glycolysis: regulation and structure/function relationships of substrate cycle enzymes. Annual Review of Nutrition 11, 465-515.

Roberts B \& Anderson PJ (1985) The purification and kinetic characterization of eel white muscle pyruvate kinase. Comparative Biochemistry and Physiology 80B, 51-56.

Shimeno S, Ming DC \& Takeda M (1993) Metabolic response to dietary carbohydrate and lipid ratios in Oreochromis niloticus. Nippon Suisan Gakkaishi 59, 827-833.

Shimeno S, Shikata T, Hosokavwa H, Masumoto T \& Kheyyali D (1997) Metabolic response to feeding rates in common carp, Cyprinus carpio. Aquaculture 151, 371-377.

Stabile LP, Klautky SA, Minor SM \& Salati LM (1998) Polyunsaturated fatty acids inhibit the expression of the glucose-6phosphate dehydrogenase gene in primary rat hepatocytes by nuclear posttranscriptional mechanism. Journal of Lipid Research 39, 1951-1963.

Steffens W (1989) Principles of Fish Nutrition, pp. 66-183. Chichester: Ellis Horwood Ltd.

Suárez MD, Hidalgo MC, García Gallego M, Sanz A \& de la Higuera M (1995) Influence of the relative proportions of energy yielding nutrients on liver intermediary metabolism of the European eel. Comparative Biochemistry and Physiology 111A, 421-428.

Towle HC, Kaytor EN \& Shih H-M (1997) Regulation of the expression of lipogenic enzyme genes by carbohydrate. Annual Review of Nutrition 17, 405-433.

Wilson RP (1994) Utilization of dietary carbohydrate by fish. Aquaculture 124, 67-80.

Windham WR (1997) Animal feed. In Official Methods of Analysis, 16th ed., pp. 4.1-4.46 [P Cunnif, editor]. Gaithersburg, MD: AOAC International.

Yamauchi T, Stegeman JJ \& Goldberg E (1975) The effects of starvation and temperature acclimation on pentose phosphate dehydrogenases in brook trout liver. Archives of Biochemistry and Biophysics 167, 13-20. 